\title{
ВЛИЯНИЕ РИСКОВ ФУНКЦИОНИРОВАНИЯ СИСТЕМЫ ЭКОНОМИЧЕСКОЙ БЕЗОПАСНОСТИ БАНКОВСКОЙ СФЕРЫ НА СОЦИАЛЬНО-ЭКОНОМИЧЕСКОЕ РАЗВИТИЕ ГОСУДАРСТВА
}

\author{
(c) 2020 Фленова Елена Викторовна \\ старший преподаватель, кафедра менеджмента и управления персоналом \\ Академия социального образования, Респ. Татарстан, Казань \\ E-mail: elenaflenova@mail.ru
}

\begin{abstract}
Анализ рисков устойчивого функционирования национальной экономики подтверждает тезис о роли инструментов управления экономической безопасностью банковской системы в обеспечении поступательной динамики макроэкономических индикаторов. Это находит отражение в прямой зависимости динамики основных макро- и мезоэкономических индикаторов от динамики показателей индикаторов состояния системы экономической безопасности банковского сектора. Разграничение понятийных конструкций «экономическая безопасность банковской системы» и «банковская безопасность» позволили сформулировать ключевые риски устойчивого функционирования банковской системы, препятствующие реализации банками имманентных им функций и влекущие неустойчивость экономической системы в целом. Использование эмпирической шкалы оценки влияния рисков функционирования системы экономической безопасности банковской сферы на состояние экономической безопасности государства позволит повысить обоснованность прогнозов динамики показателей состояния национальной экономики и экономики размещения кредитных организаций, а также разработать эффективные инструменты нейтрализации (преодоления) рискообразующих факторов.
\end{abstract}

Ключевые слова. Экономическая безопасность банковской системы, банковская безопасность, угрозы экономической безопасности банковской системы, рискообразующие факторы, устойчивость национальной экономики, макроэкономические индикаторы, инструменты управления экономической безопасностью, шкала оценки влияния рисков.

Введение. Современный этап развития мирового сообщества характеризуется повышением уровня угроз для его существования и устойчивого развития. Санитарный и экономический кризис, вызванный распространением COVID-19, выявил новые вызовы постиндустриального общества и послужил отправной точкой для научных дискуссий, посвященных инструментам воздействия со стороны государства на рискообразующие факторы, а также трансформации представлений о границах подобного вмешательства и его институциональном оформлении. При всем многообразии позиций представителей экономической науки и практики в отношении ключевых проблем жизнеобеспечения и вне зависимости от типа государственного устройства их объединяет отношение к банковской системе как к ключевому фактору, состояние которого определяет динамику и направления современной макроэкономической динамики. Одновременно признается роль денежно-кредитных регуляторов в систе- ме управления экономической безопасностью государства, а также входящих в его состав региональных и муниципальных образований. В то же время несмотря на общность исходных позиций в отношении роли банковского сектора как объекта управления и регулятора угроз следует признать, что спорными остаются категориальные конструкции, отражающие сущность явлений и процессов, а также методики оценки рисков функционирования данного сегмента экономики. Решение указанных проблем представляется необходимым для разработки обоснованных национальных и региональных прогнозов социально-экономического развития, а также для разработки и реализации программных мероприятий, обеспечивающих устойчивую поступательную динамику макро- и мезоэкономических индикаторов. Растущая неопределенность факторов внешней среды, порождающая качественно новые риски и угрозы для функционирования экономической системы в целом и банковского сегмента как ее составляющей, а 
также потребность в научно обоснованных инструментах управления ими определили выбор темы исследования, ее теоретическую и практическую значимость.

Методология. Отсутствие комплексного теоретико-методического подхода к исследованию влияния рисков устойчивого развития банковского сектора на состояние национальной и региональной экономики ограничивает гносеологический потенциал современной экономической науки. Многоаспектность проблемы исследования и растущее многообразие рискообразующих факторов предопределили необходимость обращения к работам представителей различных экономических школ и течений, в которых сформулированы ключевые положения менеджмента, теории управления рисками [5], теории управления экономической безопасностью [1; 3; 6], а также принципы функционирования банковской системы и инструменты управления ею [4]. Отдельные аспекты механизма воздействия государства и других экономических агентов на рискообразующие факторы рассматриваются в нормативных правовых и программных документах государства, в которых определен состав индикаторов экономической безопасности и их пороговые значения, а также сформулирован состав институтов, регулирующих и регламентирующих денежно-кредитную политику государства. В ходе исследования используются документы международных организаций, в том числе, рекомендации Базельского комитета, которые нашли отражение в федеральных законах и подзаконных актах [7; 8], нормативных актах Центрального банка России, а также локальные нормативные акты, принятые российскими коммерческими банками и небанковскими кредитными организациями. Для обеспечения достоверности и обоснованности выводов использованы официальные данные органов государственной статистики, отражающие динамику ряда макро- и мезоэкономических индикаторов.

Результат. Проведенное исследование показывает различие между понятиями «экономическая безопасность банковской системы» и «банковская безопасность». Под первым мы понимает устойчивое состояние банковской системы, которое позволяет ей сохранять существенные характеристики в процессе поступательного развития под влиянием изменений факторов турбулентной внешней среды. При этом субъ- ектом управления системой экономической безопасности банковского сегмента выступает государство, которое рассматривает целенаправленное воздействие на рискообразующие факторы устойчивого функционирования банковских и небанковских кредитных организаций в качестве значимого условия безопасности экономики в целом. В свою очередь, банковская безопасность определяется как безопасность отдельного банка, включающая безопасность информационную, технологическую, которые обеспечивают защиту интересов собственников, менеджеров и клиентов. Банковская безопасность включает экономическую безопасность отдельной кредитной организации как один из аспектов.

Исследование показывает, что уровень устойчивости банковской системы зависит в значительной степени от динамики показателей социально-экономического развития национальной экономики в целом и региона размещения банковских организаций. В то же время состояние банковской системы влияет на выбор и полноту реализации стратегических направлений социально-экономического развития и уровень безопасности экономической системы государства, факторы которого представлены в таблице 1.

Анализ данных таблицы 1 показал, что банковская система оказывает непосредственное влияние на уровень экономической безопасности государства, поскольку она выполняет следующие функции:

1. Активное наращивание долгосрочных ресурсов;

2. Трансформирование привлеченных средств в инвестиции;

3. Расширение ассортимента банковских услуг;

4. Повышение финансовой защиты для физических и юридических лиц.

В качестве источников долгосрочных ресурсов кредитными организациями используются привлеченные средства, классифицируемые в зависимости от отношения к размещению банковской организации на внутренние или внешние. Однако в условиях санкционных ограничений со стороны ряда зарубежных государства, а также падения экономической и финансовой активности в условиях пандемии коронавируса, привлечение внешних финансовых ресурсов является высокорисковым по причине высокой 
Таблица 1. Факторы влияния банковской системы на реализацию стратегических направлений социально-экономического развития и уровень безопасности экономической системы государства [2]

\begin{tabular}{|c|c|}
\hline $\begin{array}{l}\text { Направление экономиче- } \\
\text { ского развития }\end{array}$ & Факторы влияния банковской системы \\
\hline $\begin{array}{l}\text { Экономическая } \\
\text { реструктуризация }\end{array}$ & $\begin{array}{l}\text { Формирование сетевых банковских организаций, направленных на льготное } \\
\text { кредитование инновационного развития; } \\
\text { Использование депозитов для активизации инвестиционных вложений; } \\
\text { Наращивание долгосрочных ресурсов банковских организаций. }\end{array}$ \\
\hline $\begin{array}{l}\text { Динамизация развития } \\
\text { сектора малого и средне- } \\
\text { го предпринимательства } \\
\text { (МСП) }\end{array}$ & $\begin{array}{l}\text { Формирование льготных финансовых условий для сектора МСП; } \\
\text { Наращивание портфеля услуг для предпринимателей. }\end{array}$ \\
\hline Социальное развитие & $\begin{array}{l}\text { Увеличение объемов потребительского кредитования; } \\
\text { Наращивание портфеля услуг для населения; } \\
\text { Увеличение количества банковских организаций с актуализацией их территори- } \\
\text { ального размещения; } \\
\text { Повышение уровня защищенности депозитов населения. }\end{array}$ \\
\hline $\begin{array}{l}\text { Активизация развития } \\
\text { инновационной деятель- } \\
\text { ности }\end{array}$ & $\begin{array}{l}\text { Наращивание долгосрочных ресурсов банковских организаций; } \\
\text { Увеличение инвестиционных вложений в инновационное развитие за счет } \\
\text { средств государственных фондов. }\end{array}$ \\
\hline $\begin{array}{l}\text { Противостояние кри- } \\
\text { минальной и коррупци- } \\
\text { онной составляющим } \\
\text { деятельности }\end{array}$ & $\begin{array}{l}\text { Повышение контроля над подозрительными транзакциями в целях исключения } \\
\text { финансирования терроризма и оборота нелегальных доходов; } \\
\text { Взаимодействие посредством Банка России с иностранными банковскими } \\
\text { организациями в целях нивелирования криминальных действий в банковских } \\
\text { организациях; } \\
\text { Поддержка деятельности бюро кредитных историй. }\end{array}$ \\
\hline
\end{tabular}

волатильности национальной валютной единицы. В отношении некоторых стран, объявивших санкции, указанное привлечение является невозможным. Это актуализирует изыскание и использование внутренних источников долгосрочных ресурсов, представляющих собой сберегаемую часть доходов населения, а также средства институциональных инвесторов, включающих, в первую очередь, средства пенсионных фондов. Основная часть долгосрочных ресурсов банковских организаций представлена депозитами, то есть привлеченными средствами физических и юридических лиц, используемыми привлекающей стороной в соответствие с банковским законодательством и установленными режимами счета. Данный фактор может характеризоваться показателем нетто-активов банковской организации, отражающим уровень надежности и величины банковской организации, а также объемом привлеченных средств.

Фактор трансформации сбережений в инвестиции в настоящих условиях может быть охарактеризован показателем объема выданных кредитов юридическим лицам, или, в частности, субъектам малого и среднего бизнеса.

В силу присущих банковским организациям активности и универсальности в процессе финансовой и кредитной деятельности, харак- теризующейся наличием высококонкурентной среды и государственного регулирования, возникает необходимость повышения эффективности реализации собственных конкурентных преимуществ за счет создания и продвижения инновационных финансовых продуктов, обладающих потребительской ценностью, и способствующих удовлетворению интересов клиентов банковских организаций и, как следствие, регионального и национального социальноэкономического развития. Расширение ассортимента банковских услуг может быть реализовано за счет внедрения нового продукта банковской организации, эффективность которого может быть оценена на основе устойчивости спроса (существующего или потенциального - в зависимости от клиентской группы). Указанный индикатор может характеризоваться динамикой численности клиентов - как физических, так и юридических лиц.

В соответствие с данными Национального рейтинга кибербезопасности в 2019 году Российской Федерации принадлежит 26-е место из 160-ти участвующих стран с индикатором 64,94 баллов из 100 возможных [9]. Данный рейтинг характеризует национальный уровень потенциала противостояния киберугрозам, отражая достаточно устойчивое состояние России по дан- 
Таблица 2. Эмпирическая шкала оценки влияния рисков функционирования системы экономической безопасности банковской сферы на состояние экономической безопасности государства

\begin{tabular}{|c|c|c|c|c|c|}
\hline $\begin{array}{c}\text { Качественная } \\
\text { оценка риска }\end{array}$ & $\begin{array}{c}\text { Несуществен- } \\
\text { ный }\end{array}$ & Низкий & Умеренный & Значимый & Высокий \\
\hline $\begin{array}{c}\text { Вероятность } \\
\text { наступления } \\
\text { риска }\end{array}$ & $0,1-0,19(9)$ & $0,2-0,349(9)$ & $0,35-0,549(9)$ & $0,55-0,69(9)$ & Выше 0,7 \\
\hline $\begin{array}{c}\text { Коэффициент } \\
\text { влияния }\end{array}$ & 1 & $-1,05$ & $-1,1$ & $-1,2$ & $-1,3$ \\
\hline
\end{tabular}

ному индикатору. Однако необходимо отметить негативную тенденцию: позиция Российской Федерации в 2014 году находилась на 12-и месте, а в 2017 году - на 10-м месте, при наличии комментариев о значительном увеличении количества мероприятий противодействия мошенничеству в электронных платежных системах.

В соответствие с вышеизложенным, на основании обобщения теоретической информации по результатам исследований, посвященных количественной оценке рисков функционирования организаций, предлагается эмпирическая шкала соответствия уровня рисков, способствующая определению количественного показателя, характеризующего степень риска (таблица 2).

Выбор соответствующих уровню риска коэффициентов влияния обусловлен градацией величин коэффициента вариации, являющихся одной из характеристик степени риска и определяющий неустойчивость исследуемой ситуации. Таким образом, при наличии несущественного риска воздействие факторов функционирования банковской системы в целях повышения национальной экономической безопасности не оказывает негативного влияния на воздействие связей (коэффициент влияния = 1). Установление низкой вероятности наступления риска обусловливает применение понижающего коэффициента влияния, равного -1,05. Умеренный риск снижает позитивное влияние факторов на 1,1 . При выявлении значимого риска величина экономической безопасности банковской сферы подвергается влиянию понижающего коэффициента $-1,2$. В случае высокорисковой ситуации, аналогично качественному определению коэффициента вариации, наблюдается высокая неустойчивость развития, снижающая экономическую безопасность банковской сферы, применяется коэффициент влияния, равный $-1,3$.

Заключение. Применение предложенных коэффициентов влияния обусловливает объективизацию количественной оценки экономической безопасности банковской сферы, в соответствие с которой возможно построение адекватного прогноза социально-экономического развития, а также разработки соответствующих упреждающих или воздействующих мероприятий.

\section{Библиографический список}

1. Бухвальд Е.М.Система понятий экономической безопасности: региональный уровень / Экономическая безопасность.-2020.- Том 3.- № 1.-С. 63-78.

2. Кац И., Дружинин А. Банковская сфера и стратегия развития экономики // Проблемы теории и практики управления.-2007.- № 1.-С. 49-52.

3. Миронова О.А. Экономическая безопасность: проблемы и пути ее обеспечения // Экономика. Налоги. Право. 2015. - № 1.- С. 79-83.

4. Мельник Д. Ю. Экономическая безопасность банковской системы: теоретические и практические аспекты// Интернет-журнал «Науковедение». 2017.- Том 9. - № 5 (сентябрь - октябрь) [Электронный ресурс]. Режим доступа: https://naukovedenie.ru. Дата обращения: 14.06.2020.

5. Найт Ф.Х. Риск, неопределенность и прибыль. М.: Дело, 2003. - 360 с.

6. Сенчагов В.К.Цели, приоритеты, риски модернизации финансовой системы России» // Федерализм.2012. - № 2.- С. 7-30.

7. Указ Президента Российской Федерации от 13 мая 2017 года № 208 «О Стратегии экономической безопасности Российской Федерации на период до 2030 года» [Электронный ресурс]. Режим доступа: https:// rg.ru/2017/05/15/prezident-ukaz208-site-dok.html. Дата обращения: 10.06.2020. 
8. Указ Президента РФ от 31.12.2015 N 683 «О Стратегии национальной безопасности Российской Федерации» [Электронный ресурс]. Режим доступа: http://www.consultant.ru/document/cons_doc_LAW_191669/ Дата обращения: 10.06.2020.

9. National Cyber security index [Электронный ресурс] Режим доступа: https://ncsi.ega.ee/ncsi-index/ Дата обращения: 10.06.2020. 